\title{
「社会人リフレッシュ教育特別コース」の発足
}

\author{
静岡大学大学院情報学研究科 ${ }^{1}$
}

著者抄録 : 静岡大学大学院情報学研究科では, 今年度より「社会人リフレッシュ教育特別コース（修 土課程)」を発足させた。情報化社会の進展に伴い会社や学校などの職場では, 経営活動や教育活動 と情報技術とを的確に結び付けることのできる知見・能力を有する人材 ( “情報化推進コーディネー タ”と呼ぶ）が，求められている。本コースはそのような人材の育成を目的とするものであり，社 会人を在職のまま受け八れ, 働きながら学ぶことができる授業カリキュラムを提供するとともに, 研 究では職業上の問題意識に基づく実践的なテーマを重視している。そして, 学習と研究の成果がそ れぞれの職場に積極的にフィードバックされることを目指している。

キーワード : 社会人教育， I T ，経営の情報化，教育の情報化，情報化コーディネータ

\section{Start of Special Education Course for Adult Students: Graduate School of Informatics, Shizuoka University}

\author{
Graduate School of Informatics, Shizuoka University ${ }^{1}$
}

\begin{abstract}
Author Abstract: Graduate School of Informatics, Shizuoka University set up the Special Education Course for Adult Students in April of 2004. With the recent rapid progress in our "information society", working places of companies or schools have increasingly needed human resources who have IT management know-how, in addition to IT knowledge and proficiency. We call such human resources "coordinators for promoting information society". The Course aims at fostering such human resources and accepts members of the community as they are, providing curricula which allow them to learn and study while working. It also emphasizes practical themes for research, dealing with professional matters or problems students are encountering. The Course ultimately aims at learning and research results providing valuable feedback to students' workplaces.
\end{abstract}

Key words: Education Course for Adult Students, IT, IT-based management, IT-based education, coordinators for promoting information society

\section{1. はじめに}

情報技術は今や，あらゆる分野において必要不 可欠なものとなっている。しかし, 企業や学校現 場の中核的な実務担当者や管理者の多くは，情報 技術や情報システムに関する体系的な教育を受け ておらず，断片的な知識を自己流に習得している のがほとんどである。また, 情報系の学部卒業者 であっても, 情報技術の進歩の速さに対して必ず しもキャッチアップできている状況にはない。 近年，経済の情報化が進展し，企業では，経営
の問題として情報技術を取り込むことが, 経営の 成果に直結する環境となってきた。そして, 企業 経営と情報技術とを結び付けることのできる高度 な知見を有する人材（これを情報化推進コーディ ネータと呼ぶことにする)に対する必要性がクロー ズアップされている。しかし, 各企業が独自に人 材を育成することは困難であり, 地域によっては 自治体等の支援が行われているものの, 大学の参 加が強く望まれる状況にある.

また，学校現場においても，情報教育が重視さ れているが,これを高いレべルで推進する人材の

\footnotetext{
1 静岡大学（浜松キャンパス）大学院情報学研究科（修士課程）（†432-8011 浜松市城北3丁目5-1）Tel.053-478-1500 E-Mail：minami-t@ia.inf.shizuoka.ac.jp（研究科長 南 利明）

${ }^{1}$ Graduate School of Informatics, Shizuoka University (5-1 Johoku, 3-chome, Hamamatsu-shi, Shizuoka, 432-8011)
} 
養成は十分ではない。また, 学校の管理・運営の ための情報インフラの整備も進められており, そ れを企画し運営する人材の充実も求められている。 すなわち, 学校現場においても, 教育の情報化を 推進する「情報化推進コーディネータ」が必要で あり,教育委員会をはじめ初等·中等教育に携わっ ている教育現場からも，このような人材育成に対 する大学の参加が期待されている。

このような背景をふまえて, 静岡大学大学院情 報学研究科では, 情報技術・情報社会の最新動向 を系統的に学び直すことで職業人としての資質能 力の一段の高度化を期することを目的に, 社会人 リフレッシュ教育特別コース（定員5名）を設置し た。そして，2004年4月に第1期生学生5名を受け入 れた。

\section{2. 教育のコンセプト}

本情報学研究科ではこれまでも社会人特別選抜 入試を行ってきた。それは, 社会で職業などを経 験した人材が, 大学院に八学し一般の学生と同様 の大学院生生活を送ることを前提としている。よっ て, 入試は社会人向けであっても, 入学後は一般 学生と同じカリキュラムで学ぶこととなっている。 しかしながら,このような体制では, 企業や学校 現場で必要とされている情報化推進コーディネー タを十分に育成することはできない。
そこで，これまでの体制とは違った社会人リフ レッシュ教育特別コースを開設した。このコース は, 在職のまま職業人を受け入れ,「働きながら学 ぶ」,「職業上の問題意識を研究テーマとする」,「大 学院での学習·研究成果を職業の場にフィードバッ クする」ことをねらいとしている。

本コースの概要を図に示す（図1）。企業や学校 といった職場のニーズに対する本コースの人材育 成と人材の資質向上が示されているが, 学習研究 過程においては, 絶えず, 企業や学校とのインタ ラクション, 研究成果のフィードバックと問題の 提供を重要視している。

また, 職場のニーズは, 時代・社会情勢・国際 情勢によっても変化がもたらされるので, 新たに 生ずる問題やニーズに刘して循環的に対応するこ とを, 教育の基本コンセプトとしている。

\section{3. 授業・研究指導体制の特徵}

本コースを開設するに当たり, 情報化推進コー ディネータを育成するためにどのような授業科目 が必要か, また, 実際に職場で働きながら学ぶ環 境をどのように確保するか, などに腐心した。本 節では, 授業・研究指導体制の特徵とそれにかか わるカリキュラム上の工夫を述べる。

まず第1に, 授業, 本コースのカリキュラムでは, 大学院設置基準第14条特例を適用し, 個々に勉学

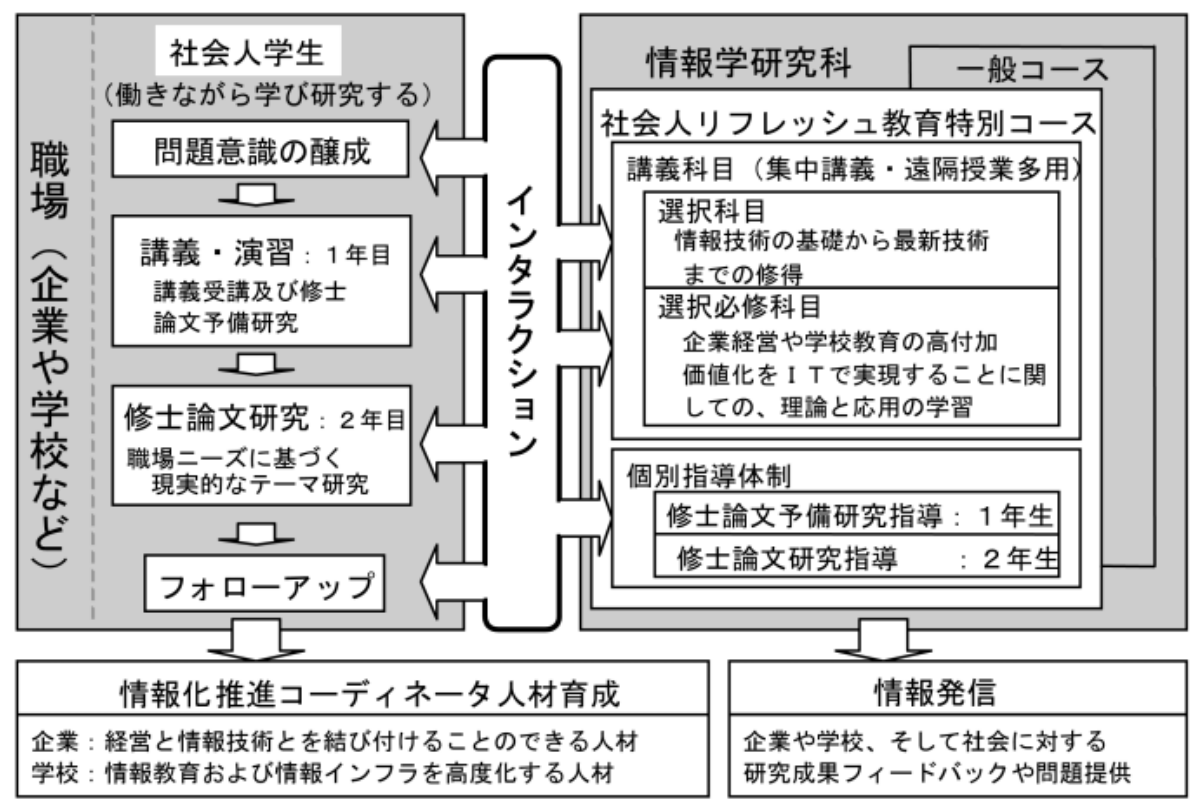

図1 社会人リフレッシュ教育特別コースの概要 
条件が異なる社会人が適切な教育を受けられるよ う, 各人の都合に合わせた柔軟な授業開講や演習, そして研究の指導ができるように配慮しており， 休日の開講や集中講義, およびインターネットを 利用した研究指導などを行うことにした。

第2に, 夜間·休日開講や集中講義に伴う事務連 絡体制や学生指導体制等については可能なかぎり インターネットを利用して行うこととした。

第3に, 従来のカリキュラムよりも必修科目を大 幅に減らし選択必修科目を増加させることによっ て,さまざまな業種の社会人リフレッシュ教育の バリエーションを可能としている。

第4に, 社会人学生を対象にした実学的な科目を 選択必修科目として6科目（組織情報化設計論, 情 報システム設計論, 実践マネジメント特論, eマーケティング特論, 情報教育カリキュラム設計 論，情報科教育法特論）を新設した。これらは社 会人として働いた経験・知識を前提として展開さ れ，実際にかかわっている（またはかかわってい た）実務に対応させた形で，現実の問題をどのよ うに解決・改善すればよいのかを考察するような 演習を取り入れた授業構成となっている。また, 大学において情報の専門教育を修得していない社 会人に対しては，情報科学の基礎・基本を短期間 で修得するための接続科目を，選択科目として準 備した。

第 5 に, 在学期間 2 年間のうち後半の 1 年間は職場 で修学できる制度とした。ここでは, 社会人学生 の職場でのニーズに基づく現実的なテーマを，指
導教員と密接な連携の下に設定する。

第6に, 最新のネットワーク技術の教育ととも に, 社会の情報化において課題である情報セキュ リティについては, 一般コースでのこれら授業の 受講を可能とすることにした。

以上が, 授業・研究指導体制の特徵とそれにか かわるカリキュラム上の工夫である。次に 4 節と 5 節で, 具体的な授業内容を詳しく見ていく。

\section{4. 授業内容}

本コースの学生は, 選択必修科目, 選択科目 (接 続科目）の中から，授業を履修する。以下にその 内容を示すことにするが, 選択必修科目が本コー スの大きな特徵となっている。

(1) 選択必修科目

社会人として働いた経験・知識を前提として展 開される授業科目であり, 大学での学問を理解す るだけではなく, 実際に現在かかわっている実務 に対応させた形で問題解決に生かせる能力の育成 を目指して, 現実の問題をどのように改善すれば よいのかをみずから考察するような授業内容とし ている。それら授業6科目の概要を下表（表1）に 示す。なお, これらの授業は一般学生も受講可能 としている。

(2) 選択科目（接続科目）

情報系の大学教育を修得せずに社会人として情 報システム系の職種に就いている者を対象に, 情 報科学の基礎・基本を短期間で修得するために設

表1 選択必修科目の授業概要

\begin{tabular}{|c|c|}
\hline 授業科目名 & 授 \\
\hline 組織情報化設計論 & 5. 授業事例 5.1. に授業内容を記述 \\
\hline 情報システム設計論 & 5. 授業事例 5.2 . に授業内容を記述 \\
\hline 情報教育カリキュラム設計論 & $\begin{array}{l}\text { 情報リテラシー, 情報を駆使した問題解決力, 論理的・システム } \\
\text { 的な思考などの能力の育成は, 学校現場に限らず, 企業内や生涯 } \\
\text { 学習の場でも必要である。このような能力を育成するための教育 } \\
\text { におけるリ設計について, その原理と事例を学ぶ }\end{array}$ \\
\hline 情報科教育法特論 & $\begin{array}{l}\text { 高等学校での教科「情報」の必修化, 小中学校での情報教育の普 } \\
\text { 及などに応じて, これを指導する教員の指導法の一段の向上が求 } \\
\text { められている。情報教育を行なう際の, 授業モデルや授業のノウ } \\
\text { ハウについて学ぶ }\end{array}$ \\
\hline 実践マネジメント特論 & $\begin{array}{l}\text { 情報社会における望ましい社会システムや経営システムについ } \\
\text { て, これをどのように計画・構築・改善していけばよいかの合理 } \\
\text { 的な方法論を, 実企業の事例を取り上げながら学ぶ }\end{array}$ \\
\hline e -マーケティング特論 & $\begin{array}{l}\text { 情報社会におけるマーケティングについて, ブランド確立や市場 } \\
\text { 開拓などにおける情報戦略論, 顧客価値創造におけるマーケデ } \\
\text { ング手法などについて, 実企業の事例を取り上げながら学ぶ }\end{array}$ \\
\hline
\end{tabular}


置しており, 情報数学特論, ネットワーク特論, プ ログラミング特論などの授業科目からなる。

ほかに, 一般コース科目として30あまりの授業 があり, 社会人学生は自由に受講が可能である。

知的インタフェース論などの情報科学系の授業 と, 情報倫理形成論, メディア法学などの情報社 会学系の授業があるのが, 文工融合を基本理念と する当情報学研究科の特徵である。

\section{5. 授業事例}

\section{1. 組織情報化設計論}

本授業は, 企業や学校などの組織経営における 課題を情報化の視点から解明し解決するための方 法論を学習することを目的とする。

具体的には, 以下の授業内容からなり, 討議や 演習を取り入れて受講生の実務に役立つ実践的な 内容としている。

(1) 情報化方法論概説

情報システムの 2,3 事例研究を基に情報化の 成功／失敗要因について討議し，仕事の仕組みの 解明と再設計（すなわち業務分析・再設計）こそ 最も重要な成功要因であることを理解する。

(2) 業務分析基礎演習

仕事の仕組みを“業務フロー”として記述する 手法を例題演習により行ったうえで, 受講者自身 の関与する業務についての業務フローを作成し, グループ討議によって課題整理を行う。

（3）業務設計基礎演習

例題による新業務設計演習をグループに分かれ て行い, 発表し討議する。なお，本授業での討議 はKJ法に類した方法を多用する。

(4) 事例研究

文献を与え自宅で学習したうえで「ITは経営を 変えるか?」について討議して, 組織経営と情報 化の要諦について理解を深める。

(5) 業務設計応用演習

受講者が先に作成した業務フローについて，業 務改革・改善課題の摘出と業務再設計とを試みる。 2004 年度は, 社会人学生 5 名（教育関係 4 名, 企 業関係1名), 一般学生 2 名の受講者であり, 社会人 学生の日程都合を配慮して, 夏休みを利用しての 前半 2 日, 後半 2 日の集中授業とした。討議や演習 を多く取り入れたことにより，大変に活気のある 授業となり，学生の満足度も高く，本授業の目的 は達成されたと言える。

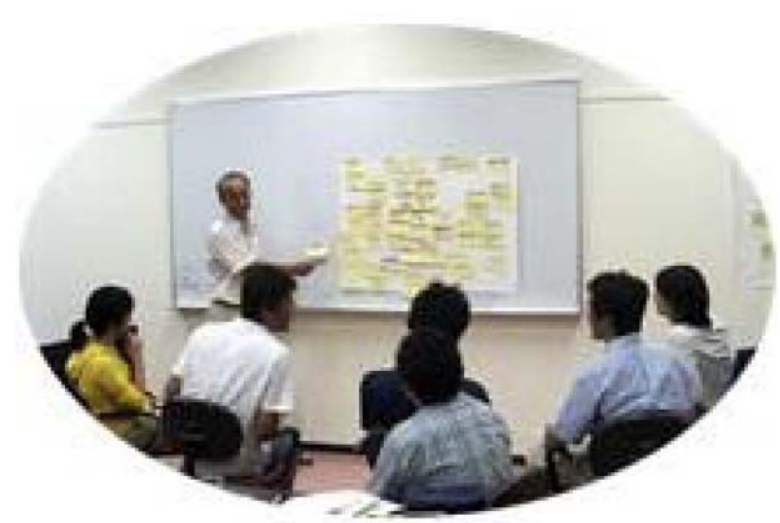

討議風景

\section{2. 情報システム設計論}

社会人学生が所属する業種における情報システ ムを例に取り上げ,これらの情報システムの設計・ 開発・運用までの流れを実務分析的に学ぶことを 目標とし, 情報システムの分析・設計・運用の理 論と実社会での現実の対応付けを図る。

内容は以下の 3 部構成から成り, 2004年度は, 前 半 2 日間で(1)と(2)の集中授業を, また後半2日間で (3)の授業を, 上記の「組織情報化設計論」の授業 に続いて夏休み期間に行った。

(1) 概念的背景概説

システムおよび情報の本質を理解し, よいシス テムが具備すべき要件を明らかにする。また, シ ステムを構築するためのいろいろなアプローチに ついて，その違いを比較する。

(2) 構造化方法論

ニーズ分析と要求定義, システム構造の理解と 図式表現, 情報の流水の分析, 蓄積情報の分析な どの方法について, 演習を交えて理解を深める。

(3) オブジェクト指向方法論を学ぶ

オブジェクト指向の概念を理解し, UML記法を 用いてユースケース分析, シナリオ分析, オブジェ クト分析などの方法について, 演習を交えて学習 し, 理解を深める。

2004年度の受講学生は, 5名の社会人であり, 共 通の実務的事例を取り上げることに難しさがあっ た。そのため, 身近で理解しやすい図書館システ ム, レストランシステム, インターネット書籍販 売システムの3つの事例についての講義と演習を 行った。学生の学習意欲も高く, 大変充実した授 業であった。 


\section{6. 受講生（小学校司書担当教諭）手記}

情報学は現代社会のさまざまな分野に影響を及 ぼしている。公共図書館の書架を見渡すと, 情報 とは無関係の分野を探すほうが難しく, 私の勤務 する教育現場もその例外ではない。

本コースを選択した動機は, 自分で学ぶことに 限界を感じたからである。情報分野の内容の多く は, 基本を学ぶ機会がないため, 私の中では保留 状態になっていた。この部分を理解しなければ次 へ進めない状況にあることはわかっているものの, 教育現場の変化は著しく, 2 年間職場を離れること に危機感を感じていた。そこで, 本コース受講と いう選択肢を知り, 受講した。そして現在, 保留 状態は徐々に解消されつつあると感じている。

本コースでは, 働きながら学びたいという社会 人に向けて, 日程や時間はもとよりカリキュラム まで便宜が図られている。

特に, 選択必修科目は, 情報学を基礎から学び 直したいという社会人に対応した内容であり, 難 しくもあったが充実した時間であった。

例えば，実際に企業へ見学に行ったり，企業の 第一線で活躍している方が講師であったり, 学び が社会と直結していたことは, 改めて社会の仕組 みや問題点を考えるよい機会となった。また, 少 人数での演習中心の学びにより, 難しい内容が咀 嚼（そしゃく）されて自分のものになったと感じ ている。

職場を離れられない社会人学生, さらには離れ たくない学生のためにも, 大学院での新たな学び の提案と内容の更なる充実を期待している。

\section{7. 将来の展開}

本コースは, 今年度に定員どおりの 5 名の社会人 学生でスタートしたばかりである。種々の課題は あるが, 幸い, 初年度 5 名の社会人学生は, 意欲と 資質が大変に高く, 授業への協力はもちろん, 課 題に関する意見交換にも積極的である。

本コースの最大の特徵は, 企業や学校といった 職場におけるニーズや社会人学生自身の問題意識 などに基づく学習・研究活動と, 本コースの提供 する講義や個別指導とが絶えず連携し双方向的に コミュニケーションをとる構成になっていること であり, 職場と大学が相互の長所を生かし, 不足 する点を相補う形で連携していくことにある。

今後も, 静岡大学大学院情報学研究科がある浜 松地域を中心に, 産業界や教育界, そして行政機 関（例えば博物館や市役所など）などからの, 社 会人学生の参加を期待しており, 産業の活性化, 教育の深化·高度化, そしてさらに地域の活性化 に最大限の貢献をしたいと考えている。

職場のニーズは, 時代・社会情勢・国際情勢に よっても変化がもたらされる。新たに生ずる問題 やニーズに対して, 職場と協調しながら対応し, また新たな問題提起を行うという, 循環的な関係 を保持し続けることが, 本コースの生命線である と認識している。さらに広い分野からのいろいろ の課題や価值観を持った社会人学生を受け入れ, より実践的で多様な教育研究を展開し, 真に求め られる能力を持った「情報化推進コーディネータ」 の育成に努めるとともに, 社会に対して, 研究成 果のフィードバックや問題提供を行っていきたい。 